for internal hemorrhoids. Mr. H. Smith in addition adrocates the practice of employing it in prolapse of the rectum. He contencis that the use of nitric acid for hæmorrhoids is superior to the operations of ligature and excision in numerous cases, of which he gives instances. As indicating his opinion on the suitubility of the same remedy in prolapse, we may quote the final paragraph of his treatise:-

"It is not necescary for me to relate more cases, as those detailed show that prolapsus of the rectum may, as well as intermal bwmorrhoids, be cured without any other operation than the judicious employment of nitric acid. It is quite surprising to see the extraordinary comfort which one or two noplications of this agent will give to patients who have been suffering years of misery. It will supersede the use of those atrocions pessaries and supports which patients every now and then bring ont of their pockets to show us, and which, independently of being very injurious from the dilatation of the gut caused by them, are excessively nasty things, and chiefly calculated to amuse old women and hypochondriacal men, who have nothing else to do but to attend to the state of their bowels."

\section{forcign deryartmont.}

INFUSION OF COFFEE IN STRANGULATED HERNA.

M. Couturier (of Merinchal, France) mentions the following case, in the Gazetste des Hopitartic of the 12th inst.:-A woman aged forty-five years was suffering from strangulated crural hernia, which was found irreducible. As the symptoms were extremely alarming, M. Couturier proposed an operation whereupon the parient stated that she would rather die than submit to it. Tnder these circumstances, her surceon remembered the snccess obtained by M. Cholut with infinsion of coffee and ordered half a pound of fresh-ground coffee to be covered with three vists of hot water, and a tumbler of the jufusion to be given every hrlf hour. He then left, after telling the friends that the case was alnost hopeless. The next day, however, he heard that the natient was much better; that after the fourth tnmbler the enmonr had lost half its size, and had quite disappeared with the fifth tumbler. Soon after the reduction, three motions took place; but the patient was for the next twenty-four hours extremely feverish, owing appasently to the large quantity of cofiee she hal :aken.

\section{DR. CORYISART ON THE PANCREAS.}

Thrs talented physiologist has sent a new paper on the Digestive Facnltios of the Pancreatic Juice to the Academy of Medicine of Paris, being a seculul to a paper on the same subject presented in 1857. This new contribution to experimental physiology by Dr. Corvisart has been referred to the committee appointed to award the prizes on this branch of medical science.

OPHTHALMOSCOPE FIXED UPON THE PATIEXT.

M. Gicimerte de Grandnont, a medical student, has just brought before the Academy of Medicine of Paris an apparatus, which fixes upon the patient's face the lens used for examining the eye. The apparatus is composed of a concave plate, which fits the bridge of the nose; to this plate are addel ordinary spectacle frames, which, by lying on the circuinference of the orbits, give the instment mach steadiness, favoured by an elastic band running round the head. To the same plite is fixed, at right angles with the face, a short socket, in the interior of which is a box which carries a lens, movable in every direction. A serew, which moves the box, allows the observer to change the fucal distance of the lens. When the apparatus is placed upon the patient, and the lens is brought into the axis of the pupil, the surgeon, taking with his right houd the retlecting mirror, illumines the interior of the eye. This manipulation will be greatly facilitated by the patient's head being directed with the observer's left hand, which remains free.

M. Gillette conceives that this apparatus affords the following advantages :-

1. It prevents the blinking, which is inevitable with other instruments.

2. It fatigues patients less than other ophthslmoscopes.

3. It allows the most inexperienced observer to examine the interior of the eye.
4. It gives facilities for several persons to examine the same patient in succession, without the necessity of moving the instrument.

5. The observer has one hand free, which, being applied to the vertex of the patient, may direct the head to the most firvourable position.

6. It is simpler and more readily adjusted than the mounten ophthalmoscope; and does not require, like the instrument held by the hand, a dexterity which is only the result of seve. ral mouths' practice.

\section{A SUBSTITUTE FOR LINT.}

To the Editor of THe LANCET.

Sir,-Perbaps you can find room in The Lancer for the following description of a nseful dressing for suppurating wounds, which is extensively used now in the Parisian hos pitals, and which I have been using for some months as a good and very cheap substitute for lint, over which it has, in many cases, obvious advantages. I have Anglicized it by the name of "pink," as pinking is the process by which it is made. It is merely cheap cotton perforated by a common punch. The long-cloth is folded some fourteen times, and holes are driven through it with a hammer and a sixpenny punch on a piece of lead. The holes are about one-eighth of an inch in diameter, and twice their breadth from each other. My firm having been for many years surgeons to Messrs. Curtis and Harvey's powder. mills, I have had opportunities of testing it in buras and other large suppurating surfaces. These being extremely sensitive, do not require the removal of the pink so frequently as lint or other applications, as the pus passing through the perforations is easily removed with a soft sponge, which cannot be dons with other applications, nor will the highly vascular granula. tions in burns bear the sponge when uncovered. I have found it very useful in gunshot wounds, and in compound fractures, where, as a perforated bandage, it gives support without con fining the discharge, which never accumulates under it; and when removed, the surfice is covered with healthy lymph, withont yois. Mir. Ashbee, the intelligent manager of Messrs. Curtis's powder nills, has promised to prepare some linen or cotton by their elaborate machinery, if possible; in the meantime, the hospital patient, nearly convalescent, would be grateful for the occupation to relieve his monotony, and the cheapness of material and instruments makes it wortly of trial. Any ointment may be spread on it, and where large pieces are used, it can be rewashed.

I am, Sir, yours obediently,

Hocnslow, 1559

$$
\text { J. R. A. DovgLAS, M.R.C.S., }
$$

Formerly House-Surg. Middlesex Hosp.

\section{DUTIES AND EMOLUMENTS OF COLONIAL SURGEONS.}

To the Editor of TurE LAXCET.

Sir,-A correspondent ("A. B. C.") in THE LANCET of last week makes an inquiry on the above subject. I have been surgeon in one colony and acted as temporary colonial surgeon in another. In New Zealand and Australia the appointments are now in the hands of the local governments, and the pay varies from $£ 200$ to $£ 600$ per annum. The duties are to attend all Government servants, and anything professional the authorities may order. In the diferent settlements on the cowst of Africa the pay is $£ 400$ and upwards, and the risk to life is such that I was the only colonial surgeon who did not die at Cape Coast for twenty years, and $r$ was put on board a ship and sent home after three attacks of African fever. The a ppointment is in the hands of the Secretary of State for the Colonies. There is no half-pay for any length of service in any part of the world, and no recognition of any claim for another appointment elsewbere.

Notwithstanding my service on the Gold Coast, short in point of time it is true, but deadly in climate, and most injurious to my future health, I never could (having no interest with great aristocrats) procure anything from the Colonial Office. I was told I could go back to Cape Coast if I pleásed; and though many men were sent to good things in other colo. nics, I, who bad alreally served, never got anything.

I would advise no one to serve the Colonial Office for any sum, or in any locality. There is no such mismanaged department in all the Government as the Colonial.
$J_{1} ! r, 1399$
I am, Sir, yours, \&c. 